\title{
PENGARUH LAMA PENYINARAN LAMPU LED MERAH, BIRU, KUNING TERHADAP PERTUMBUHAN MICROGREEN KANGKUNG (Ipomoea reptant)
}

\author{
Lizda As'adiya ${ }^{1^{*}}$, Indiyah Murwani ${ }^{1}$ \\ ${ }^{1}$ Departemen Agroteknologi, Fakultas Pertanian Universitas Islam Malang \\ JL. MT. Haryono No. 193 Malang 65144, Jawa Timur, Indonesia \\ *Korespondensi : lisda.asadiya@gmail.com
}

\begin{abstract}
Abstrak
Microgreen merupakan sayuran yang dapat dipanen sekitar 7-14 hari setelah perkecambahan yang memiliki kandungan gizi dan vitamin yang lebih tinggi dibandingkan sayuran yang ditanam biasa. Penelitian ini bertujuan untuk mengetahui interaksi antara jenis lampu dan lama penyinaran serta pengaruh jenis LED merah, biru, kuning dan lama penyinaran LED merah, biru, kuning terhadap pertumbuhan microgreen kangkung. Penelitian ini merupakan percobaan box menggunakan Rancangan Percobaan Petak Terbagi. Hasil penelitian menujukkan bahwa terjadi interaksi antara jenis lampu dan lama penyinaran terhadap pertumbuhan microgreen kangkung. Kombinasi perlakuan C3T1 (LED Kuning + 6 jam) menghasilkan panjang tanaman tertinggi yaitu $6,47 \mathrm{~cm}$ pada $7 \mathrm{HST}$, jumlah daun sebesar 2,00 helai untuk semua perlakuan. Perbedaan jenis lampu pada microgreen kangkung berpengaruh nyata terhadap pertumbuhan dimana lampu LED Biru menghasilkan jumlah daun tertinggi yaitu 2,00 helai pada $14 \mathrm{HST}$. Bobot segar per kotak tertinggi yaitu $18,36 \mathrm{~g}$. Sedangkan LED Kuning menghasilkan panjang tanaman tertinggi $9,42 \mathrm{~cm}$ pada $14 \mathrm{HST}$, jumlah daun tertinggi sebesar 2,00 helai $14 \mathrm{HST}$, panjang akar tertinggi yaitu $7,22 \mathrm{~cm}$, bobot kering per kotak tertinggi 1,03 g. Perbedaan lama penyinaran pada microgreen kangkung berpengaruh nyata terhadap pertumbuhan dimana Lama penyinaran 6 Jam menghasilkan panjang akar tertinggi yaitu 7,96 cm, bobot segar per kotak tertinggi yaitu 23,17 g, bobot kering per kotak tertinggi yaitu 1,87 g. Lama penyinaran 12 Jam menghasilkan panjang tanaman tertinggi yaitu $10,41 \mathrm{~cm}$ pada $14 \mathrm{HST}$, jumlah daun tertinggi yaitu 2,00 helai. Berdasarkan hasil penelitian ini dapat direkomendasikan bahwa budidaya microgreen kangkung dalam kotak tanam dapat dilakukan dengan menggunakan penyinaran selama 6 jam dan memperhatikan unsur mikro yang mempengaruhi microgreen untuk pertumbuhan yang lebih baik.
\end{abstract}

Kata Kunci : Microgreen, Kangkung, Lampu LED Merah, Biru, Kuning,

\section{Abstract}

Microgreens are vegetables that can be harvested about 7-14 days after germination which has a higher nutrient and vitamin content than commonly grown vegetables. This study aims to determine the interaction between the type of light and the duration of lighting and the effect of the types of red, blue, yellow LEDs and red, blue, yellow LED lighting on the growth of kangkung microgreen. This research is a box experiment using a Split Plot Experiment Design with 9 treatments and 3 replications. The results showed that there was an interaction between the type of lamp and the duration of lighting to the growth of kangkung microgreen. The combination of C3T1 treatment (Yellow LED + 6 hours) produced the highest plant length, namely $6.47 \mathrm{~cm}$ at $7 \mathrm{DAS}$, the number of leaves was 2.00 for all treatments. The different types of lamps in kangkung microgreen had a significant effect on growth, where the blue LED light produced the highest number of leaves, namely 2.00 leaves at 14 DAS. The highest fresh weight per box was $18.36 \mathrm{~g}$. 
While the Yellow LED produced the highest plant length of $9.42 \mathrm{~cm}$ at 14 DAS, the highest number of leaves was 2.00 pieces 14 DAS, the highest root length was $7.22 \mathrm{~cm}$, the highest dry weight per box was $1.03 \mathrm{~g}$. The difference in lighting time on kangkung microgreen has a significant effect on the growth, where the 6 hours lighting duration produces the highest root length, namely $7.96 \mathrm{~cm}$, the highest fresh weight per box is $23.17 \mathrm{~g}$, the highest dry weight per box is $1.87 \mathrm{~g}$. The length of 12 hours of lighting resulted in the highest plant length, namely $10.41 \mathrm{~cm}$ at 14 DAS, the highest number of leaves was 2.00 leaf blade. Based on the results of this study it can be recommended that the cultivation of kangkung microgreen in the box experiment can be using lighting for 6 hours and pay attention to the microelements that affect the microgreen for better growth.

Keywords : Microgreen, Kangkung, Red, Blue, Yellow, LED lights

\section{Pendahuluan}

Microgreen merupakan sayuran yang dapat dipanen sekitar 7-14 hari setelah perkecambahan. Microgreen merupakan jenis sayuran yang memiliki kandungan gizi dan vitamin yang lebih tinggi dibandingkan sayuran yang ditanam biasa. Akan tetapi kandungan gizi dan vitamin pada sayuran microgreen akan semakin menurun jika disimpan terlalu lama, namun dapat menjadi substitusi dari sayuran yang harus ditanam di lahan yang sudah berkurang di perkotaan ini (Kaiser, 2018).

Jenis tumbuhan microgreen memiliki kandungan senyawa bioaktif seperti antioksidan, vitamin, flavanoid, karotenoid lebih tinggi daripada tumbuhan yang dipanen setelah dewasa sekitar 25-30 hari. Tingginya kandungan nutrisi pada microgreen disebabkan karena tumbuhan masih mengalami proses katabolis. Proses katabolis merupakan proses penyediaan zat gizi untuk pertumbuhan tanaman melalui reaksi hidrolisa dari cadangan zat gizi yang terdapat dalam biji. Selain itu, pada fase microgreen terjadi peningkatan hormon pertumbuhan yang mempengaruhi peningkatan senyawa fenolik.

Menurut data Shoutheast Asian Food ang Agriculture Science and Technology (SEAFAST) Center IPB (2017) di Indonesia, sayur masih kurang diminati oleh masyarakat dan konsumsi nya masih sekitar 180 gram per hari lebih kecil dari rekomendasi WHO yaitu 250 gram per hari. Salah satu sayuran yang dikonsumsi oleh masyarakat yaitu kangkung. Kandungan gizi dalam 100 gram kangkung meliputi: energi sebesar 29 kal, protein 3 gram, lemak 0,3 gram, karbohidrat 5,4 gram, serat 1 gram, kalsium $73 \mathrm{mg}$, fosfor $50 \mathrm{mg}$, besi 2,5 mg, vitamin A 6.300 SI, vitamin B1 0,07 mg, Vitamin C 32 mg, Klorofil 25 mg/l, Air 89,7 gram (Astawan, 2009). 
Microgreen tidak membutuhkan banyak perawatan setelah penyebaran benih ke media. Cahaya tambahan diberikan dengan cara kontinyu yaitu lampu menyala selama 46 jam terus menerus. Pada umumnya penambahan cahaya pada tanaman untuk memberi pengaruh hari panjang dilakukan mulai saat tanam sampai 2 minggu setelah tanam. Penambahan cahaya diberikan dengan menggunakan lampu LED dengan warna yang berbeda. Waktu pemberian yang ideal dimulai pukul 18.00 sampai 22.00 WIB. Tanaman sayuran dapat ditanam dalam rumah plastik dengan intensitas cahaya yang tinggi akan menghasilkan batang dan daun panjang serta besar dibandingkan ditanam diluar rumah kaca. Selain itu, diperlukan pencegahan dan penanggulangan serangan hama dan penyakit (Edi dan Bobihoe, 2012).

Salah satu cara yang dapat di gunakan untuk memanipulasi cahaya matahari adalah dengan menggunakan lampu LED atau Growing Light . Kualitas cahaya sangat penting ketika menggunakan cahaya buatan untuk tumbuh tanaman. Sumber cahaya harus memiliki kualitas cahaya yang tepat untuk memulai dan mempertahankan fotosintesis. Klorofil dapat menyerap panjang gelombang merah (600-700 nm) sampai biru (400-500 $\mathrm{nm}$ ), sehingga lampu yang dirancang untuk per tumbuhan tanaman harus memancarkan panjang gelombang. Lampu LED dapat memancarkan warna cahaya yang dapat mempercepat proses fotosintesis. Warna biru untuk fase vegetatif dan warna merah untuk fase generatif (Soeleman \& Rahayu, 2013) .

Lampu merah yang paling awal digunakan untuk uji budidaya tanaman kualitas cahaya, adalah pertumbuhan tanaman yang normal harus kualitas cahaya, jumlah kebutuhan biologis dalam berbagai kualitas cahaya monokromatik pertama, sumber cahaya buatan dari kualitas cahaya yang paling penting. Bahan yang dihasilkan di bawah lampu mer ah membuat tanaman tumbuh lebih tinggi, cahaya merah melalui pigmen fotosintesis sangat efektif untuk keperluan aktivitas fotosintesis tumbuhan serta untuk perkembangan generatif tanaman seperti pemanjangan batang, sintesis karbohidrat, mendukung untuk sintesis asam karboksilat pada buah dan sayur; namun menghambat asimilasi nitrogen. sementara cahaya biru menghasilkan bahan untuk mempromosikan akumulasi protein dan non-karbohidrat, untuk menambah berat badan. Cahaya biru mempengaruhi cahaya tanaman, morfogenesis cahaya, pembukaan stomata, dan fotosintesis daun (Lingga, 2002). 


\section{Bahan dan Metode}

Penelitian dilaksanakan bulan Mei 2020 sampai dengan Juli 2020 bertempat di Desa Bumiaji dengan ketinggian tempat 1500 mdpl dan di Laboratorium Fisiologi Fakultas Pertanian Universitas Islam Malang.

Alat yang digunakan dalam penelitian ini adalah LED strip 5 meter 40 watt yang terdiri dari Lampu LED warna merah, Lampu LED warna biru, Lampu LED warna kuning berukuran $25 \mathrm{~cm}$, sprayer, timbangan analitik, box container 15 Liter, labu takar $50 \mathrm{ml}$, tray atau wadah, kamera, alat tulis, Luxmeter, Alat Timer.

Bahan yang digunakan dalam penelitian ini adalah benih kangkung varietas 'sejati', media pasir steril, vermikompos.

Penelitian ini merupakan percobaan box menggunakan Rancangan Percobaan Petak Terbagi (Split Plot) dengan 9 perlakuan dan 3 ulangan. Macam perlakuan yang diujikan adalah : C1T1 (LED Merah + 6 jam), C2T1 (LED Biru + 6 jam), C3T1 (LED Kuning + 6 jam), C1T2 (LED Merah + 12 jam), C2T2 (LED Biru + 12 jam), C3T2 (LED Kuning + 12 jam), C1T3 (LED Merah + 18 jam), C2T3 (LED Biru + 18 jam) dan C3T3 (LED Kuning + 18 jam). Faktor Pertama : C1 = Lampu LED Merah, C2 = Lampu LED Biru, C3 = Lampu LED Kuning. Faktor Kedua : T1 = Lama Penyinaran 6 Jam, T2 = Lama Penyinaran 12 Jam, T3 = Lama Penyinaran 18 Jam.

Variabel yang diamati meliputi : Panjang microgreen $(\mathrm{cm})$ dengan cara mengukur tanaman mulai dari leher akar sampai pucuk daun dengan interval pengamatan 7 dan 14 hari setelah tanam, jumlah daun (helai) dengan cara menghitung daun yang telah membuka sempurna, panjang akar $(\mathrm{cm})$ dengan cara mencabut tanaman pada saat panen dan mengukur panjang akar microgreen, bobot segar per Kotak ( $\mathrm{g}$ ) dilakukan dengan cara menimbang seluruh tanaman dalam wadah pada satu kotak tanam setelah panen dalam kondisi segar, bobot kering per Kotak (g) dilakukan dengan cara menimbang tanaman yang sudah dioven selama $2 \times 24$ jam pada suhu $70^{\circ} \mathrm{C}$.

Data hasil pengamatan yang diperoleh dianalisis dengan menggunakan Rancangan percobaan petak terbagi (split plot), analisis ragam (uji $\mathrm{F}$ ) dengan taraf nyata $5 \%$, dan apabila menunjukkan pengaruh nyata, maka dilanjutkan dengan uji lanjut BNJ dengan taraf $5 \%$. 


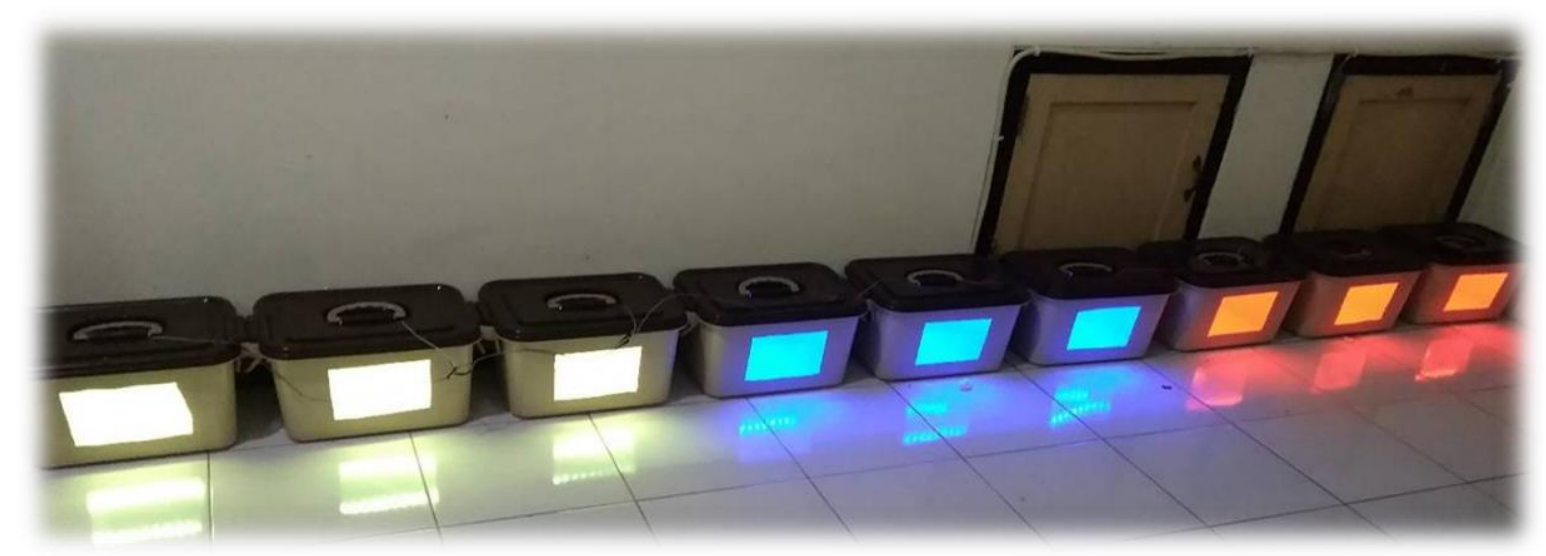

Gambar 1. Aplikasi penyinaran LED merah, biru dan kuning

\section{Hasil dan Pembahasan}

\section{Kondisi Umum Penelitian}

Intensitas cahaya dalam kotak penanaman dari lampu LED yang digunakan untuk warna merah sekitar 158-195 Lux, warna kuning sekitar 396 - 425 Lux, dan warna biru sekitar 400-658 Lux. Sedangkan intensitas matahari di luar kotak penanaman pada pagi dan sore hari yaitu sekitar 5738 - 8873 Lux. Pengukuran intensitas cahaya di dalam ruang tanaman bertujuan untuk mengetahui pengaruh intensitas cahaya terhadap pertumbuhan kangkung (Ipomea reptans). Pengukuran intensitas cahaya yang dihasilkan oleh beberapa perlakuan dari perbedaan warna lampu yaitu lampu berwarna merah, lampu berwarna biru dan lampu berwarna kuning dengan jenis lampu yaitu LED.

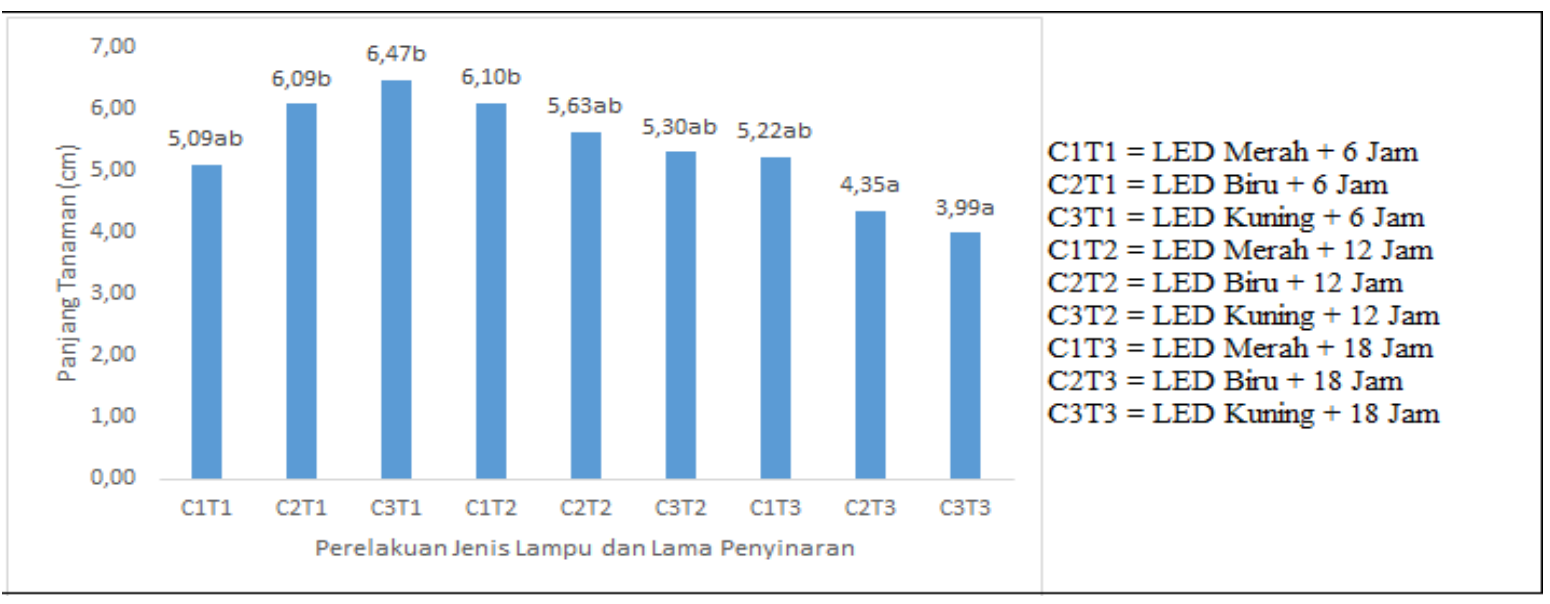

Gambar 2. Pengaruh jenis lampu dan lama penyinaran terhadap panjang tanaman (cm) pada umur 7 hst 
Gambar 2. menunjukkan bahwa pada umur 7 HST perlakuan C3T1 (Lampu LED Kuning + Lama penyinaran 6 Jam) menunjukkan rata-rata panjang tanaman tertinggi dan berbeda nyata dengan perlakuan C2T3 (Lampu LED Biru + Lama Penyinaran 18 Jam) dan C3T3 (Lampu LED Kuning + Lama Penyinaran 18 Jam) tetapi tidak berbeda nyata dengan perlakuan lain.

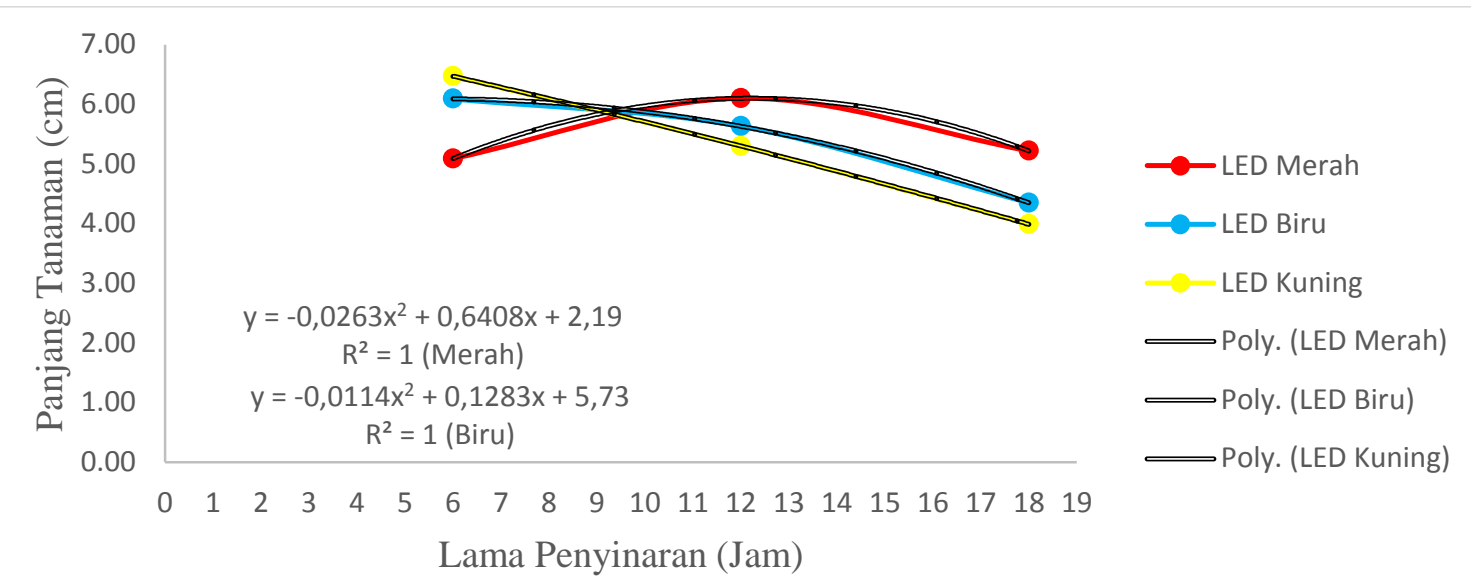

Gambar 3. Interaksi jenis lampu dan lama penyinaran terhadap panjang tanaman (cm) pada umur 7 hst

Uji regresi digunakan untuk menentukan titik optimum hubungan dari jenis lampu dan lama penyinaran terlihat pada gambar 3 . Hasil uji regresi pada variabel panjang tanaman (cm) umur 7 HST untuk LED merah dan LED biru menunjukkan pola kuadratik yang artinya semakin lama penyinaran akan terjadi peningkatan panjang tanaman sampai pada titik optimum lalu mengalami penurunan. Diperoleh besarnya titik optimum pada LED merah 12,18 jam dengan panjang tanaman 6,09 cm. Sedangkan, pada LED biru titik optimum lama penyinaran adalah 5,63 jam atau lebih pendek dari perlakuan dalam penelitian ini dengan panjang tanaman $6,09 \mathrm{~cm}$. Artinya pada penyinaran cahaya merah akan maksimal jika disinari selama 12 jam dan cahaya biru akan maksimal jika disinari selama 5-6 jam, jika diatas 6 jam panjang tanaman LED biru cenderung menurun. Dan untuk LED kuning menunjukkan bahwa semakin lama penyinaran maka hasil semakin menurun. Tanaman hanya menerima sedikit cahaya berwarna kuning, warna lampu kuning diperlukan untuk fotosintesis dalam jumlah sedikit sehingga tidak berpengaruh terhadap pertumbuhan tanaman.

Menurut Syafriyudin \& Ledhe (2015) bahwa lampu warna biru bagus untuk pertumbuhan tanaman karena klorofil banyak menyerap cahaya biru sehingga fotosintesis 
berlangsung optimal dan untuk lampu warna merah bagus untuk pertumbuhan tanaman karena fitokrom-pigmen merah menyerap cahaya merah sehingga ukuran tanaman lebih besar.

Pertumbuhan tanaman kangkung meningkat sampai pada titik optimum lalu mengalami penurunan karena mengalami gejala fotodestruktif akibat pemberian cahaya terus menerus. Fotodestruktif merupakan tingginya intensitas cahaya yang mengakibatkan fotosintesis tidak bertambah lagi karena tanaman mengalami batas titik jenuh cahaya sehingga bukan sebagai energi tetapi sebagai perusak.

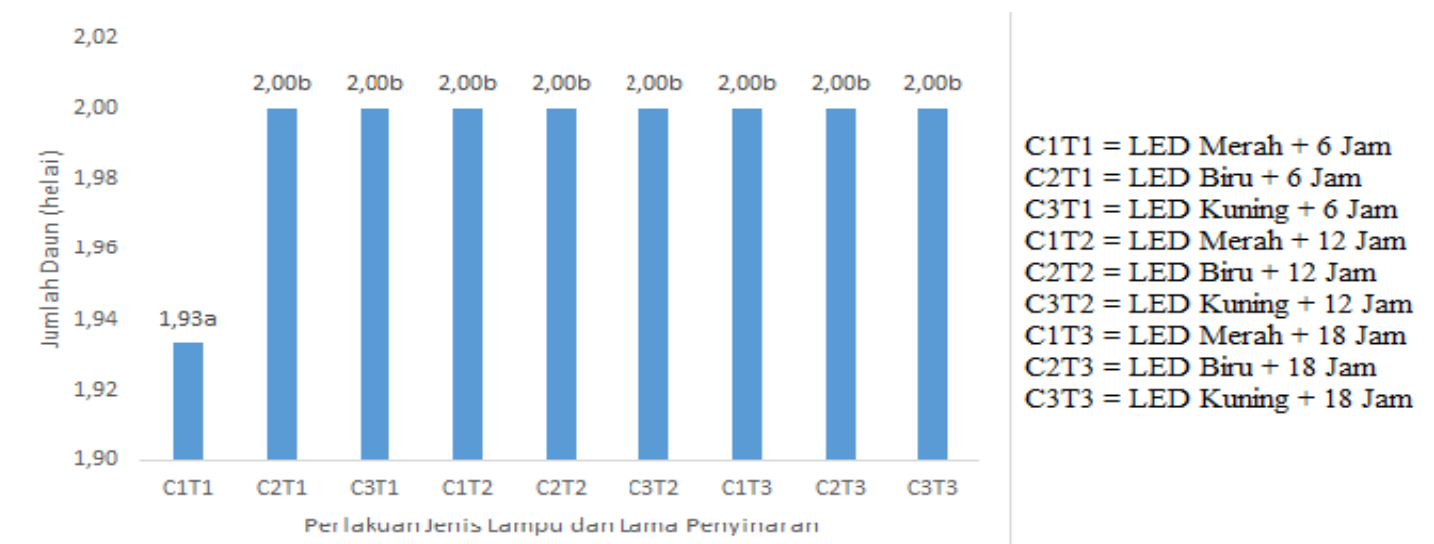

Gambar 4. Pengaruh jenis lampu dan lama penyinaran terhadap jumlah daun (helai) pada umur 14 hst

Gambar 4. Menunjukkan bahwa terjadi interaksi perlakuan jenis lampu dan lama penyinaran pada umur 14 HST semua perlakuan tidak berbeda nyata namun berbeda nyata dengan perlakuan C1T1 (Lampu LED Merah + Lama penyinaran 6 Jam). Daun yang dihasilkan lebih terang dan segar karena reaksi fotosintesis, penambahan cahaya merah dianjurkan karena memiliki panjang gelombang paling besar yaitu 626-750nm. Semakin lama penyinaran lampu LED dapat mempercepat pertumbuhan daun (kotiledon) microgreen dan proses fotosintesis optimal tetapi menghambat petumbuhan batang sehingga tanaman tampak memanjang mengikuti arah cahaya.

Menurut Silvikultur (2007) cahaya berpengaruh terhadap arah pertumbuhan akar dan perluasan atau tidak bergulungnya daun. Cahaya akan menghambat pertumbuhan batang sehingga pada bagian batang yang tidak terkena cahaya menjadi lebih panjang.

Daun merupakan komponen utama suatu tumbuhan dalam proses fotosintesis. Proses fotosintesis akan optimal apabila daun yang menjadi tempat utama proses fotosintesis berlangsung semakin banyak jumlahnya dan semakin besar ukurannya, 
adanya sinar yang lebih tinggi intensitasnya lebih baik daripada sinar dengan intensitas yang rendah (Pertamawati, 2010).

Pada perlakuan C1T1 (LED Merah + Lama penyinaran 6 Jam) menunjukkan bahwa tanaman mendapatkan intensitas cahaya yang sedikit sehingga tanaman tidak melakukan fotosintesis dengan sempurna dan menyebabkan daun tidak tumbuh seragam.

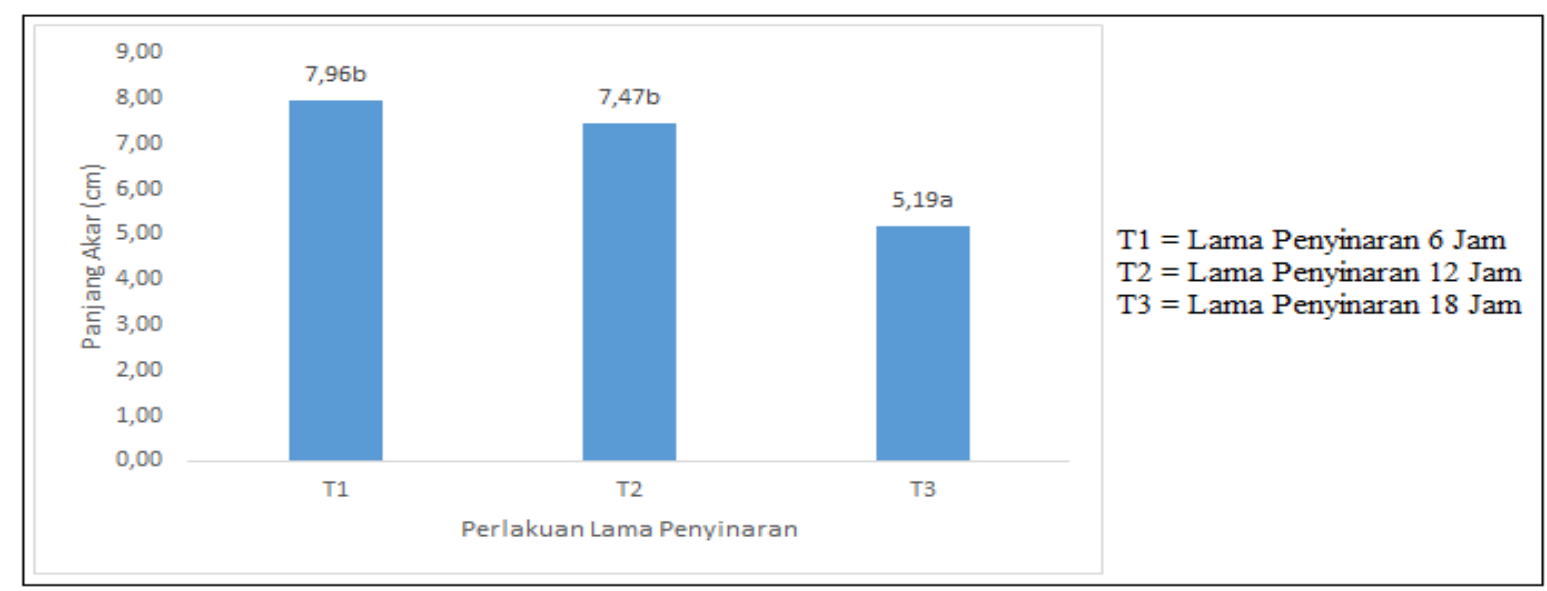

Gambar 5. Pengaruh lama penyinaran terhadap panjang akar (cm).

Gambar 5. Menunjukkan bahwa secara terpisah lama penyinaran berpengaruh nyata terhadap panjang akar. Perlakuan T1 (Lama penyinaran 6 Jam) menunjukkan hasil tertinggi daripada perlakuan yang lain. Semakin lama penyinaran maka semakin pendek akar karena kebutuhan air yang kurang dan ketersediaan hara yang sudah di ambil oleh tanaman lainnya, apabila perakaran tumbuh dengan baik maka pertumbuhan bagian tanaman yang lain akan berkembang baik pula, karena akar dapat menyerap unsur hara yang dibutuhkan tanaman. Penggunaan lampu kuning dapat memproduksi panjang akar dengan baik tetapi tidak dengan pertumbuhannya. 


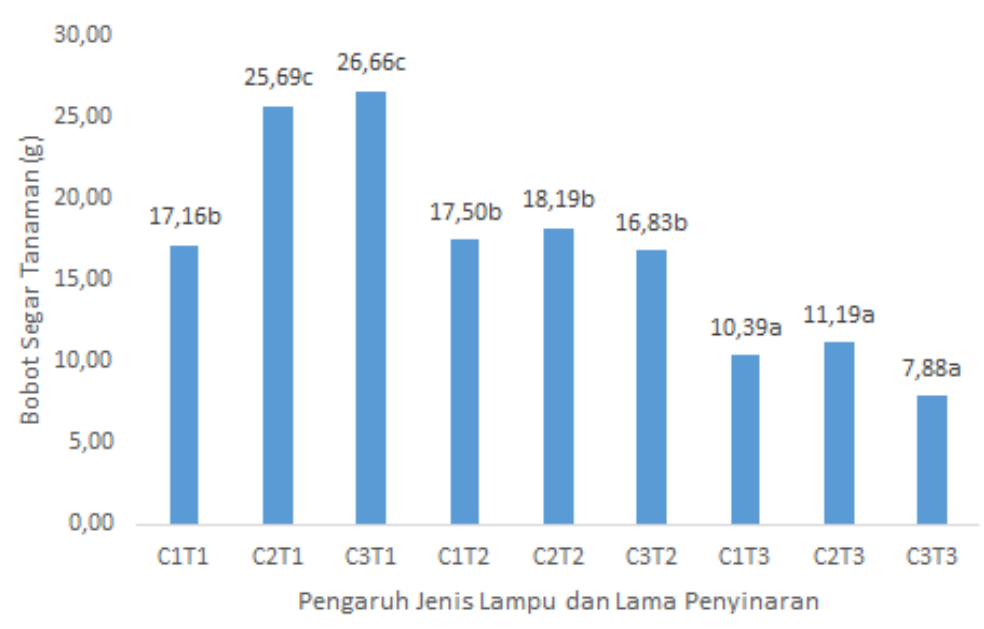

$\mathrm{C} 1 \mathrm{~T} 1=\mathrm{LED}$ Merah $+6 \mathrm{Jam}$ $\mathrm{C} 2 \mathrm{~T} 1=\mathrm{LED} \mathrm{Biru}+6 \mathrm{Jam}$ $\mathrm{C} 3 \mathrm{~T} 1=\mathrm{LED}$ Kuning $+6 \mathrm{Jam}$ $\mathrm{C} 1 \mathrm{~T} 2=\mathrm{LED}$ Merah $+12 \mathrm{Jam}$ $\mathrm{C} 2 \mathrm{~T} 2=\mathrm{LED}$ Biru $+12 \mathrm{Jam}$ C3T2 = LED Kuning $+12 \mathrm{Jam}$ C1T3 $=$ LED Merah $+18 \mathrm{Jam}$ $\mathrm{C} 2 \mathrm{~T} 3=\mathrm{LED}$ Biru $+18 \mathrm{Jam}$ C3T3 = LED Kuning + $18 \mathrm{Jam}$

Gambar 6. Pengaruh jenis lampu dan lama penyinaran terhadap bobot segar tanaman (g)

Gambar 6. Menunjukkan bahwa terjadi interaksi antara jenis lampu dan lama penyinaran perlakuan C3T1 (Lampu LED Kuning + Lama penyinaran 6 Jam) memiliki bobot segar per tanaman tertinggi tetapi tidak berbeda nyata dengan perlakuan C2T1 (Lampu LED Biru + Lama penyinaran 6 Jam). Artinya setiap tanaman memiliki kemampuan tumbuh dengan baik dan memiliki kandungan air tinggi sehingga mempengaruhi bobot segar per tanaman. Semakin lama penyinaran maka bobot segar tanaman akan menurun begitu juga dengan kandungan air terdapat di dalam tanaman.

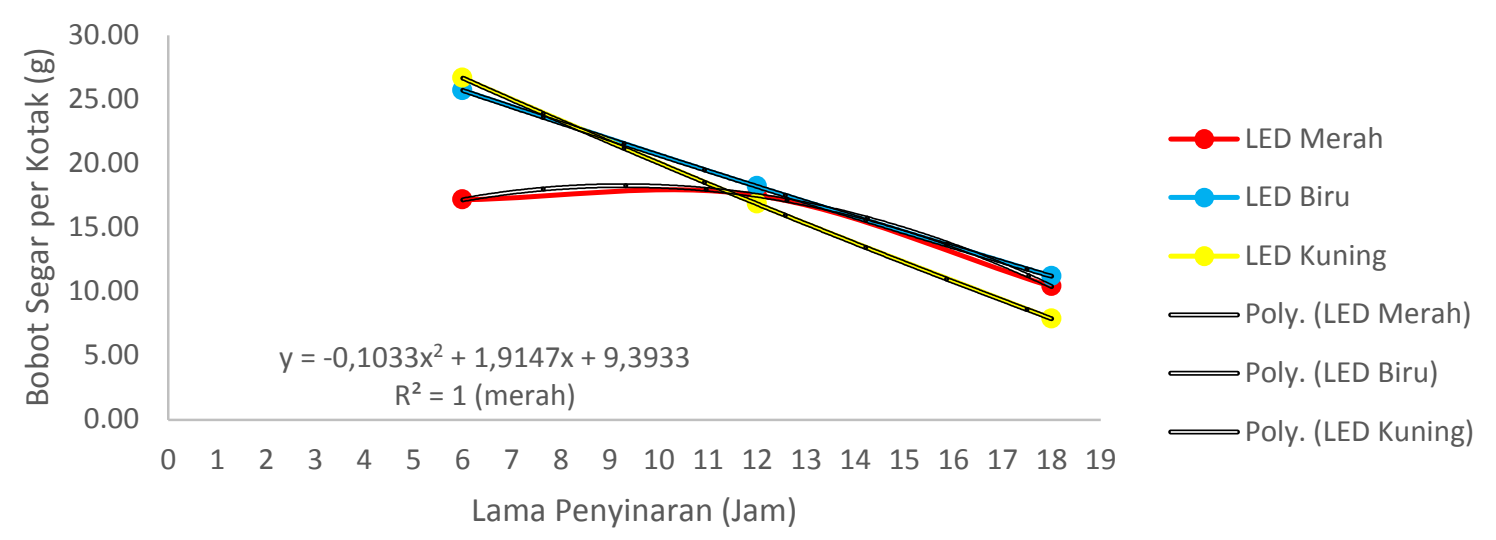

Gambar 7. Interaksi lama penyinaran dan warna cahaya terhadap bobot segar tanaman

Uji regresi digunakan untuk menentukan titik optimum hubungan dari jenis lampu dan lama penyinaran terlihat pada gambar 7. Hasil uji regresi pada variabel bobot segar tanaman (g) untuk LED merah menunjukkan pola kuadratik dengan nilai $R^{2}=1$ yang artinya semakin lama penyinaran akan terjadi peningkatan bobot segar tanaman sampai 
pada titik optimum lalu mengalami penurunan. Persamaan regresi $Y=-0,1033 X^{2}+1,9147$ $X+9,3933$ dan nilai $R^{2}=1$, diperoleh besarnya titik optimum 9,27 jam dan bobot segar tanaman 18,26 gram. Artinya pada cahaya merah bobot segar per kotak akan maksimal jika disinari selama 9-12 Jam. Menurut Syafriyudin \& Ledhe (2015) bahwa bertambahnya bobot segar menunjukkan kandungan air yang tinggi, menyerap hara dan aerasi yang baik. Warna cahaya merah bagus untuk pertumbuhan tanaman karena fitokrom-pigmen merah menyerap cahaya merah sehingga ukuran tanaman lebih besar.

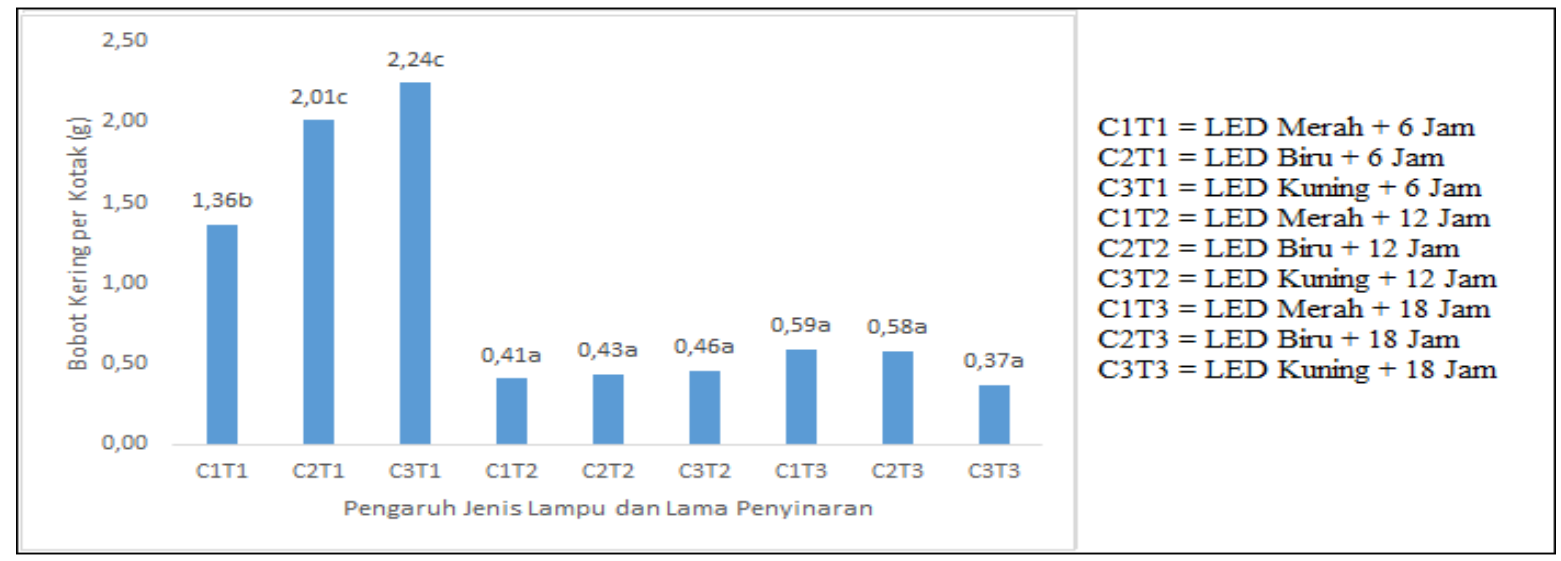

Gambar 8. Pengaruh jenis lampu dan lama penyinaran terhadap bobot kering tanaman (g)

Gambar 8. Menunjukkan bahwa pada perlakuan C3T1 (Lampu LED Kuning + Lama penyinaran 6 Jam) memiliki bobot kering tanaman tertinggi tetapi tidak berbeda nyata dengan perlakuan C2T1 (Lampu LED Biru + Lama penyinaran 6 Jam).

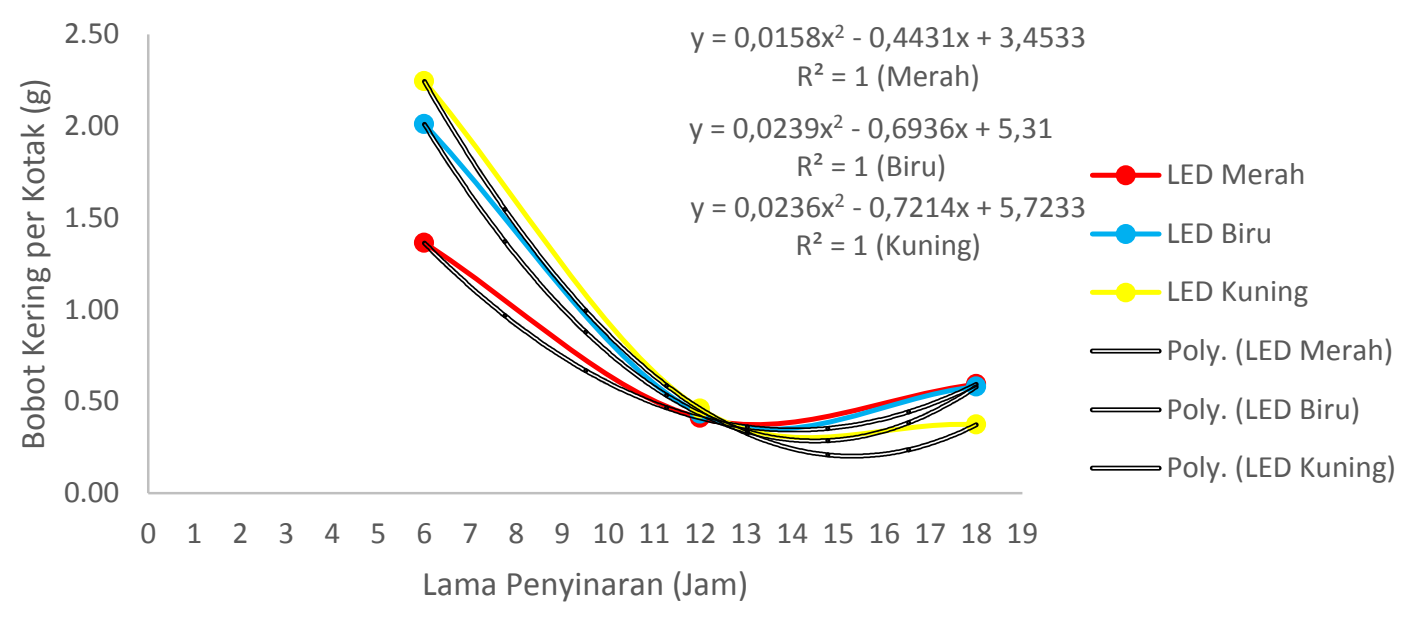

Gambar 9. Interaksi lama penyinaran dan warna cahaya terhadap bobot kering tanaman

(g) 
Gambar 9. Menunjukkan bahwa terjadi penurunan yang sangat tajam untuk semua perlakuan pada lama penyinaran 12 jam namun dapat meningkat pada lama penyinaran 18 jam. Hasil uji regresi pada variabel bobot kering per Kotak (g) menunjukkan bahwa untuk LED merah, LED biru dan LED kuning menunjukkan pola kuadratik dengan nilai $\mathrm{R}^{2}=$ 1 yang artinya semakin lama penyinaran akan terjadi penurunan bobot kering tanaman sampai pada titik minimum lalu mengalami peningkatan bobot. Diperoleh besarnya nilai minimum LED merah 14,02 jam dengan bobot kering tanaman 0,35 gram , LED Biru 14,51 jam dengan bobot kering tanaman 0,28 gram, LED Kuning 15,28 jam dengan bobot kering tanaman 0,21 gram. Artinya pada semua cahaya untuk bobot kering tanaman akan maksimal jika disinari selama 14 -18 Jam. Hal ini sesuai bahwa berat kering dapat diperoleh dengan maksimal jika tanaman mendapatkan intensitas cahaya penuh. Berat kering dari hasil panen yang diperoleh merupakan hasil peningkatan asimilasi $\mathrm{CO}_{2}$ bersih selama terjadinya pertumbuhan vegetatif tanaman (Perwitasari dkk., 2012). Pada perlakuan lama penyinaran 6 jam memiliki bobot tertinggi hal ini dikarenakan tanaman lebih padat, walaupun tanaman mengalami etiolasi karena kekurangan cahaya dan batang tidak kokoh menyebabkan daun lebih lebar dan tipis.

\section{Kesimpulan dan Saran}

\section{Kesimpulan}

Terjadi interaksi antara jenis lampu dan lama penyinaran terhadap pertumbuhan microgreen kangkung. Kombinasi perlakuan C3T1 (LED Kuning + 6 jam) menghasilkan panjang tanaman tertinggi yaitu $6,47 \mathrm{~cm}$ pada $7 \mathrm{HST}$, jumlah daun sebesar 2,00 helai untuk semua perlakuan. Perbedaan jenis lampu pada microgreen kangkung berpengaruh nyata terhadap pertumbuhan. Jenis lampu LED Biru menghasilkan jumlah daun tertinggi yaitu 2,00 helai pada 14 HST. Bobot segar per kotak tertinggi yaitu 18,36 g, LED Kuning menghasilkan panjang tanaman tertinggi $9,42 \mathrm{~cm}$ pada $14 \mathrm{HST}$, jumlah daun tertinggi sebesar 2,00 helai 14 HST, panjang akar tertinggi yaitu 7,22 cm, bobot kering per kotak tertinggi $1,03 \mathrm{~g}$. Perbedaan lama penyinaran pada microgreen kangkung berpengaruh nyata terhadap pertumbuhan. Lama penyinaran 6 Jam menghasilkan panjang akar tertinggi yaitu $7,96 \mathrm{~cm}$, bobot segar per kotak tertinggi yaitu 23,17 g, bobot kering per kotak tertinggi yaitu $1,87 \mathrm{~g}$. Lama penyinaran 12 Jam menghasilkan panjang tanaman tertinggi yaitu $10,41 \mathrm{~cm}$ pada $14 \mathrm{HST}$, jumlah daun tertinggi yaitu 2,00 helai. 


\section{Saran}

Berdasarkan hasil penelitian ini perlu dilakukan penelitian lebih lanjut dengan interval penyinaran 1-2 jam sampai pada batas 12 jam untuk mengetahui kondisi optimal kotak tumbuh untuk meningkatkan pertumbuhan dan kualitas nutrisi microgreen.

\section{DAFTAR PUSTAKA}

Astawan, Made. 2009. Panduan Karbohidrat Terlengkap. Jakarta: PT Gramedia. Pustaka.

Edi, S dan J.Bobihoe. 2012. Budidaya Tanaman Sayuran. Balai Pengkajian Teknologi Pertanian. Jambi. 54 hal.

Lingga, P. 2002.Hidroponik Bercocok Tanam Tanpa Tanah. Penebar Swadaya. Jakarta

Pertamawati, P. 2010. Pengaruh Fotosintesis Terhadap Pertumbuhan Tanaman Kentang (Solanium tuberosum L.) dalam Lingkungan Fotoautrotrof Secara Invitro. Jurnal Sains dan Teknologi Indonesia. 12(1): 31-37.

Perwitasari, B., Tripatmasari, M., dan Wasonowati, C. (2012). Pengaruh media tanam dan nutrisi terhadap pertumbuhan dan hasil tanaman pakchoi (Brassica juncea L.) dengan sistem hidroponik. Agrovigor: Jurnal Agroekoteknologi, 5(1), 14-25.

Silvikultur. 2007. Sumber Cahaya Matahari. Jakarta: Pakar Raya.

Soeleman, S dan D. Rahayu. 2013. Halaman Organik: Mengubah Taman Rumah Menjadi

Taman Sayuran Organik Untuk Gaya Hidup Sehat. PT Agro Media Pustaka. Jakarta Selatan.

Syafriyudin, S., dan Ledhe, N. T. 2015. Analisis pertumbuhan tanaman krisan pada variabel warna cahaya lampu LED. Jurnal Teknologi, 8(1), 83-87. 